\title{
A COMPARISON OF THE PHYSIOLOGICAL RESPONSES OF THREE PINE SPECIES IN DIFFERENT BIOCLIMATIC ZONES IN TUNISIA
}

\author{
CHERIF, S. ${ }^{12^{*}}-$ EZZINE, O. ${ }^{3}-$ KHOUJA, M. L. ${ }^{3}-$ NASR, Z. ${ }^{2}$ \\ ${ }^{1}$ Faculty of Sciences of Bizerte (FSB), University of Carthage, 7021 Zarzouna, Tunisia \\ ${ }^{2}$ LR161INRGREF01 Laboratory of Management and Valorization of Forest Resources, \\ National Institute for Research in Rural Engineering Water and Forest (INRGREF), University \\ of Carthage, Bp 10, 2080 Ariana, Tunisia \\ ${ }^{3}$ LR161INRGREF03 Laboratory of Forest Ecology, National Institute for Research in Rural \\ Engineering Water and Forest (INRGREF), University of Carthage, Bp 10, 2080 Ariana, \\ Tunisia \\ (phone: +216-97-135-047) \\ *Corresponding author \\ e-mail: sameh.cherif@gmail.com \\ (Received 12 $2^{\text {th }}$ Mar 2019; accepted $11^{\text {th }}$ Jul 2019)
}

\begin{abstract}
Increasing aridity attributed to climate change is the main threat to the diversity and survival of Mediterranean forests including Tunisian pine species. The impact of this climatic condition in three pine species was examined in order to detect their responses to drought and guide their selection. Three Tunisian pine species: Pinus halepensis, Pinus brutia and Pinus canariensis growing in different climatic zones: humid, sub-humid, and semi-arid were studied in two months March and July 2016. Measurements carried out within this study are leaf gas exchange, twig water potential, and soil water content. The results showed a decrease in stomatal conductance and twig water potential in July in all pine species with increase in vapor pressure deficit and low soil water content. Pinus halepensis, $P$. canariensis and $P$. brutia had stronger stomatal control in semi-arid, sub-humid and humid climate, respectively $(62,95$ and $\left.63 \mathrm{mmol} \mathrm{m}^{-2} \mathrm{~s}^{-1}\right)$ and had higher stem water potential; for P. halepensis (-2.04 MPa) in semi-arid climate; for P. canariensis and P. brutia (-2.21, -2.39 MPa) in sub-humid and humid climate, respectively. Pinus halepensis, $P$. canariensis and $P$. brutia are better adapted to semi-arid, sub-humid and humid climates, respectively. Nevertheless, $P$. halepensis is considered the most resistant species as that could maintain higher photosynthesis, stomatal control and water use efficiency particularly in semi-arid climate. These findings help to assess the interaction between species and climate on the physiological response of pine species in mid-summer water deficit, and to select among these species the most resistant for future reforestation programs.
\end{abstract}

Keywords: drought, leaf gas exchange, water potential, Mediterranean forest, genetic variability

\section{Introduction}

Mediterranean forest tree species are exposed to a range of pressures (RamirezValiente et al., 2010) and are mainly vulnerable to drought (Allen et al., 2010; Choat et al., 2012). An increase in aridity is particularly expected in the Mediterranean regions and, is the main threat to the diversity and the survival of forest trees (Peñuelas et al., 2017). Pine forests are one of Mediterranean forest species that may be threatened by rising temperatures and reduced precipitations (Manzanera et al., 2016).

To resist to these hydric stress conditions (Rubio-Casal et al., 2010; Letts et al., 2011), Pinus species may develop mechanisms of tolerance or avoidance (David et al., 2007; Mittler, 2002). Resistance to high temperature and drought strongly differs among 
plant species (Matías et al., 2012) being correlated to transpiration, hydraulic adaptations (Martínez-Vilalta et al., 2009) and water use efficiency (Warren et al., 2001). Plants protect themselves from excessive water losses (diffusion out of the leaf) under water-limited environments through a reduction of stomatal conductance (gs), which in turn leads to less carbon uptake (diffusion of $\mathrm{CO}_{2}$ into the leaf) and possibly subsequent physiological stress (McDowell et al., 2008; Will et al., 2013), reduction of transpiration (Bréda et al., 1993; Granier et al., 2008), that has been recognized as the main environmental factor limiting plant photosynthesis on the global scale (Nemani et al., 2003).

This situation underlines the need to study leaf gas exchange as indicators of the ecophysiological tolerance of pine forests (Manzanera and Martinez-Chacon, 2007). Thus, pines species maintain rather constant leaf water potential in soils with low water status and/or under high evaporative demand (Martinez-Vilalta et al., 2004). Water use efficiency (WUE) is a critical metric parameter that quantifies the trade-off between photosynthetic carbon assimilation and transpiration at the leaf level (Farquhar et al., 1982). Leaf gas exchange and water potential variables were studied on three Mediterranean pine tree species located in three bioclimatic zones in Tunisia.

Aleppo pine (Pinus halepensis Mill.) is an important forest tree in the Mediterranean region (Klein et al., 2011). Its continental range extends from northern Africa and Middle East, up to southern Mediterranean Europe. It is native and the most abundant pine species in Tunisia (You et al., 2016). The majority of Aleppo pine forests are located in central and northwestern Tunisia, mainly in Kasserine, Kairouan, Kef, Seliana and Zaghouan (Ayari et al., 2012).

Calabrian pine (Pinus brutia Ten.), native to the eastern Mediterranean, can be found in many southern Mediterranean countries. It is the most pine specie that widely distributed in Turkey (Kucuk et al., 2012). Because of their drought tolerance, they are well adapted to dry summer conditions (Lopéz et al., 2016). In Tunisia, this species was introduced in 1960 in Souiniet, Tebaba, et Jebel Abderrahmane (Khouja et al., 2002).

Canary pine (Pinus canariensis) is an endemic species of the Canary Islands (de Nascimento et al., 2009). Despite its small distribution area (western islands, occupying much of La Palma, Tenerife, El Hierro and Gran Canaria, the species grows across a wide climate (from xeric conditions to mixed forest). In Tunisia, this species was introduced since 1965 in Souiniet, Henchir Naam, Jebel Abderrahmane (Khouja, 2001).

The purpose of this study was: (i) to assess drought tolerance of three pine species from the gas exchange data and water potential, (ii) to detect if climate has an effect on the degree of tolerance of species to drought, and (iii) to select the most droughts tolerant pine species. Therefore, our objective was to compare the physiological responses to drought in three pine species, Calabrian pine (Pinus brutia), Canary pine (Pinus canariensis) and Aleppo pine (Pinus halepensis), in different bioclimatic zones of Tunisia.

\section{Materials and methods}

\section{Study sites}

The study was carried out in three different arboretums (Fig. 1) on three pine species (Pinus halepensis, P. brutia and P. canariensis). The first, Souiniet "SNT", is located in northwest Tunisia (Table 1). The shrub layer is composed of trees of Arbutus unedo, 
Erica scoparia, Erica arborea, Myrtus communis, Phillyrea media, Halimium halimofolium, Cistus salvifolius and trees of Quercus suber

The second, Jebel Abderrahmane "JAB", is located in northeast Tunisia. Vegetation consists of Mediterranean maquis with Quercus coccifera, Erica arborea, Calycotome intermedia, Halimium halimofolium, Pistacia lentiscus, and Phillyrea media.

The third arboretum, Henchir Naam "HNM", is located in northwest Tunisia and is characterized by a semi-arid climate with moderate winters and hot dry summers. Pine trees: $P$. halepensis, $P$. brutia and $P$. canariensis are found in forest mosaics along with other tree species, including Picris echioides, Phalaris truncata, Brassica amplexicaulis, Euscari comosum and Centaurea nicaensis.
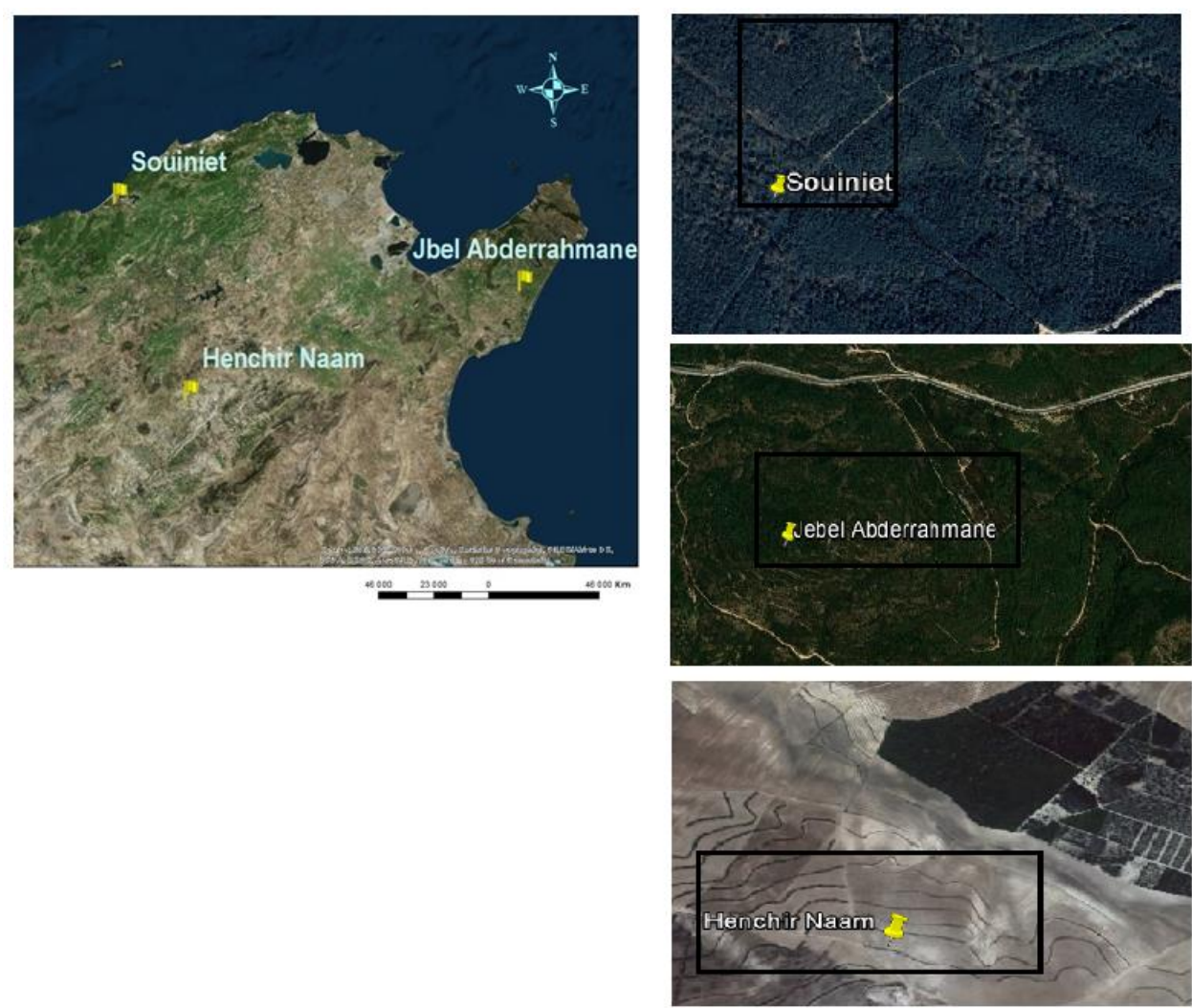

Figure 1. Localisation map of three experimental stations Souiniet, Jebel Abderrahmane and Henchir Naam Tunisia forest

Table 1. Geographical and climatic characteristics of three sites in which pine species grow

\begin{tabular}{c|c|c|c|c|c}
\hline Sites & Climate & Latitude (N) & Longitude (E) & $\begin{array}{c}\text { Altitude } \\
\text { (m a.s.l) }\end{array}$ & $\begin{array}{c}\text { Mean annual } \\
\text { precipitation (mm) } \\
(\mathbf{1 9 9 7 - 2 0 1 6 )}\end{array}$ \\
\hline Souiniet & Humid & $36^{\circ} 47^{\prime} 920^{\prime \prime}$ & $8^{\circ} 48^{\prime} 495^{\prime}$, & 492 & 1749.885 \\
Jebel Abderrahmane & Sub-humid & $36^{\circ} 40^{\prime} 086^{\prime}$ & $10^{\circ} 40^{\prime} 582^{\prime}$ & 255 & 611.751 \\
Henchir Naam & Semi-arid & $36^{\circ} 13^{\prime} 258^{\prime \prime}$ & $9^{\circ} 10^{\prime} 374^{\prime}$ & 450 & 479.513 \\
\hline
\end{tabular}

Figure 2 shows the monthly distribution of precipitation and temperature in 2016 at the three sites Souiniet, Jbel Abderrahmane and Henchir Naam. 
(a)

(b)
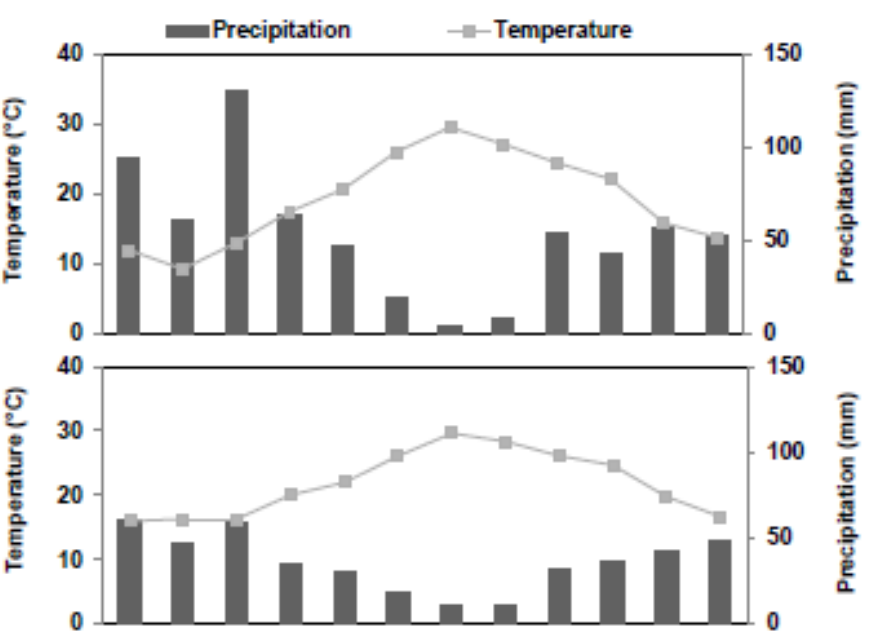

(C)

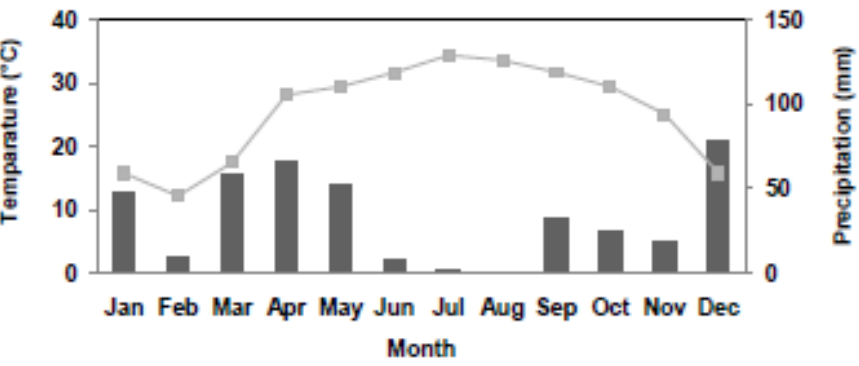

Figure 2. Climatograph of study site: (a) Souiniet site (humid climate), (b) Jbel Abderrahmane (sub-humid) and (c) Henchir Naam (semi-arid). The climatograph illustrates the monthly distribution of precipitation $(P)$ and temperature $(T)$ in 2016

\section{Sampling}

Three experiments were carried out in this study: leaf gas exchange, twig water potential, and soil water content on 11th in the month of March and July 2016 in SNT, $\mathrm{JAB}$, and HNM.

Three different trees of each pine species were considered of a high of $13.5 \pm 2.5 \mathrm{~m}$ and mean diameter at breast height $(\mathrm{DBH})$ of $16 \pm 0.3 \mathrm{~cm}$. From each tree, three branches were collected. Thus, a total nine branches of each pine species were taken for leaf gas exchange (Santiago and Mulkey, 2003). The measurements of leaf gas exchange and twig water potential were taken immediately after the collection of branches.

\section{Leaf gas exchange measurements}

Leaf gas exchange were measured using a Licor $6400 \circledR($ Li-Cor, Lincoln, NE, USA) on two-year old needles leaves. At the top of each tree, three lateral branches $90 \mathrm{~cm}$ in length were cut with pruning shears from three different trees of each pine species $(\mathrm{n}=27)$ in the morning between 06:00 and 08:00 a.m, and immediately measured in the field. Branches placed in a bucket containing cold water during the measurements to maintain leaf gas exchange at a constant level. Photosynthetic rate of the leaves was measured at the ambient $\mathrm{CO}_{2}$ concentration (400 ppm) with an open infrared gas analysis system (Li-Cor 6400-40 equipped with a red-blue LED source; Li-Cor Inc., Lincoln, NE, USA). Measurements for attached leaves were operated at $25{ }^{\circ} \mathrm{C}$ leaf 
temperature and at an airflow rate of $300 \mathrm{~cm} 3 \mathrm{~min}^{-1}$. The vapor pressure deficit was kept at $1.2 \pm 0.2 \mathrm{kPa}$. During the experiment, leaf temperature was maintained at $25{ }^{\circ} \mathrm{C}$, photon flux density at $1500 \mu \mathrm{mol} \mathrm{m} \mathrm{s}^{-2} \mathrm{~s}^{-1}$, ambient $\mathrm{CO}_{2}$ molar ratio $(\mathrm{Ca})$ at $400 \mathrm{ppm}$ and humidity of the incoming air were kept at $60 \%$. The variables measured were: leaf stomatal conductance ( $\mathrm{gs}$, in $\mathrm{mmol} \mathrm{H}_{2} \mathrm{O} \mathrm{m}^{-2} \mathrm{~s}^{-1}$ ), net carbon assimilation ( $\mathrm{An}$, in $\mu \mathrm{mol}$ $\mathrm{CO}_{2} \mathrm{~m}^{-2} \mathrm{~s}^{-1}$ ), and transpiration $\left(\mathrm{Tr}\right.$, in $\mathrm{mmol} \mathrm{H}_{2} \mathrm{O} \mathrm{m}^{-2} \mathrm{~s}^{-1}$ ). The instantaneous water use efficiency (WUE, in $\mu \mathrm{mol} \mathrm{CO} \mathrm{Col}^{-1} \mathrm{H}_{2} \mathrm{O}$ ) was determined according to Equation 1:

$$
W U E=\frac{A n}{T r}
$$

\section{Twig water potential (TWP)}

Water potential was measured at mid-day between 12:00 and 14:00 on three small twigs $(5-7 \mathrm{~cm}$ long) from the considered trees using a Scholander pressure chamber (SKPM 1400®, Skye Instruments Ltd., Powys, UK) (Scholander et al., 1965).

\section{Soil water content}

Soil water content (SWC) was monitored using a time domain refractometry (TDR, Trase system I, Soil Moisture Equipment Corp., and USA) for the three sites.

\section{Statistical analysis}

Data analysis were done using Analysis of Variance ANOVA (SAS version 9.0) by GLM procedure and the mean values of species were compared using SNK test (Student-Newman-Keuls) tests at $95 \%$ confidence interval $(\mathrm{P}<0.05)$. Pearson correlation coefficient was used to evaluate the correlations between physiological parameters studied.

\section{Results}

\section{Gas exchange measurements at the leaf level}

Drier conditions during the summer had a strong effect on gas exchange activity. Leaf gas exchange revealed significant differences in all variables (carbon net assimilation, transpiration and water use efficiency) between species $(\mathrm{p}<0.001)$ and sites $(\mathrm{p}<0.001)$, except for stomatal conductance where there was a significant difference between species $(\mathrm{p}<0.05)$ but no difference between sites $(\mathrm{p}=0.145)$. For any given species, there were differences among sites $(\mathrm{p}<0.001)$ except for stomatal conductance in Pinus canariensis $(\mathrm{p}=0.812)$. For any given site, there were differences among species $(\mathrm{p}<0.001)$. The interaction between species $\mathrm{x}$ sites was significantly $(\mathrm{p}<0.001)$ (Table 2).

At the leaf level, An was lower for all pine species in July compared to March, except for $P$. halepensis, which registered the highest values. Moreover, P. halepensis showed a sharp decrease (52\%) in An from March to July in semi-arid climate $(\mathrm{p}<0.001)$ than the other two species. For P. canariensis, there was a slight difference in reduction of An between humid, sub-humid and semi arid climates $(44.07 \%, 41.77 \%$ 
and $48.7 \%)$. While for P. brutia, the reduction of An was $(51 \%, 47.56 \%$ and $46.23 \%)$ in humid, sub-humid and semi arid climates (Table 2).

Transpiration rate, $(\mathrm{Tr})$ was significantly lower in July than in March $(\mathrm{p}<0.001)$ and between sites $(\mathrm{p}=0.006)$. Pinus canariensis, $P$. halepensis and $P$. brutia showed a sharp decrease from March to July $(\mathrm{p}<0.001)$ in sub- humid, humid and in semi-arid climates. It was $(77.72 \%, 77.5 \%$ and $82.30 \%$, respectively) (Table 2).

Water use efficiency rate, (WUE) was significantly different between months and species $(\mathrm{p}<0.001)$. Higher WUE values were measured in July in semi-arid climate. The overall means were $\left(17.44\right.$ and $\left.15.52 \mu \mathrm{mol} \mathrm{CO} \mathrm{mol}^{-1} \mathrm{H}_{2} \mathrm{O}\right)$, in P. halepensis, and $P$. brutia, respectively except for $P$. canariensis the highest value was measured in subhumid climate $\left(15.03 \mu \mathrm{mol} \mathrm{CO} 2 \mathrm{~mol}^{-1} \mathrm{H}_{2} \mathrm{O}\right)$.

There was also a difference in water use efficiency between climates for the same species however, in $P$. canariensis the difference was more pronounced between humid and semi-arid (7.71 $\left.\mu \mathrm{mol} \mathrm{CO}_{2} \mathrm{~mol}^{-1} \mathrm{H}_{2} \mathrm{O}, 8.5 \mu \mathrm{mol} \mathrm{CO}_{2} \mathrm{~mol}^{-1} \mathrm{H}_{2} \mathrm{O}\right)$ and JAB $\left(15.03 \mu \mathrm{mol} \mathrm{CO}_{2} \mathrm{~mol}^{-1} \mathrm{H}_{2} \mathrm{O}\right)$.

Table 2. Net assimilation rate $\left(\mu \mathrm{mol} \mathrm{CO}_{2} \mathrm{~m}^{-2} \mathrm{~s}^{-1}\right)$, transpiration rate $\left(\mathrm{mmol} \mathrm{H}_{2} \mathrm{O} \mathrm{m} \mathrm{m}^{-2} \mathrm{~s}^{-1}\right)$, stomatal conductance $\left(\mathrm{mmol} \mathrm{m} \mathrm{m}^{-2}\right)$, and water use efficiency $\left(\mu \mathrm{mol} \mathrm{CO}_{2} \mathrm{~mol}^{-1} \mathrm{H}_{2} \mathrm{O}\right)$ in March and July of Pinus canariensis, Pinus halepensis, P. brutia in Souiniet, Jebel Abderrahmane and Henchir Naam. Mean \pm SE with distinct letters are significantly different at $5 \%$ (SNK test)

\begin{tabular}{c|c|c|c|c|c|c|c}
\hline \multirow{2}{*}{ Variable } & \multirow{2}{*}{ Species } & \multicolumn{5}{|c|}{ Site/month } \\
\cline { 3 - 8 } & & \multicolumn{2}{|c|}{ SNT } & \multicolumn{2}{c|}{ JAB } & \multicolumn{2}{c}{ HNM } \\
\cline { 3 - 8 } & & March & July & March & July & March & July \\
\hline \multirow{3}{*}{ An } & PC & $5.65 \pm 0.06^{\mathrm{c}}$ & $3.16 \pm 0.08^{\mathrm{c}}$ & $7.23 \pm 0.01^{\mathrm{b}}$ & $4.21 \pm 0.045^{\mathrm{b}}$ & $5.96 \pm 0.11^{\mathrm{c}}$ & $3.06 \pm 0.22^{\mathrm{c}}$ \\
& PH & $6.24 \pm 0.22^{\mathrm{b}}$ & $3.43 \pm 0.05^{\mathrm{b}}$ & $7.1 \pm 0.11^{\mathrm{b}}$ & $4.12 \pm 0.07^{\mathrm{a}}$ & $8.99 \pm 0.06^{\mathrm{a}}$ & $4.36 \pm 0.06^{\mathrm{a}}$ \\
& PB & $8.38 \pm 0.02^{\mathrm{a}}$ & $4.12 \pm 0.25^{\mathrm{a}}$ & $8.2 \pm 0.09^{\mathrm{a}}$ & $4.3 \pm 0.44^{\mathrm{a}}$ & $6.64 \pm 0.13^{\mathrm{b}}$ & $3.57 \pm 0.08^{\mathrm{b}}$ \\
\hline \multirow{3}{*}{ Tr } & PC & $1.42 \pm 0.03^{\mathrm{a}}$ & $0.41 \pm 0.02^{\mathrm{a}}$ & $1.23 \pm 0.12^{\mathrm{b}}$ & $0.28 \pm 0.01^{\mathrm{c}}$ & $1.53 \pm 0.05^{\mathrm{a}}$ & $0.36 \pm 0.03^{\mathrm{a}}$ \\
& PH & $1.2 \pm 0.11^{\mathrm{b}}$ & $0.27 \pm 0.01^{\mathrm{c}}$ & $1.18 \pm 0.12^{\mathrm{b}}$ & $0.33 \pm 0.01^{\mathrm{a}}$ & $0.82 \pm 0.01^{\mathrm{c}}$ & $0.25 \pm 0.01^{\mathrm{b}}$ \\
& PB & $1.45 \pm 0.04^{\mathrm{a}}$ & $0.32 \pm 0.05^{\mathrm{b}}$ & $1.4 \pm 0.21^{\mathrm{a}}$ & $0.31 \pm 0.01^{\mathrm{b}}$ & $1.3 \pm 0.21^{\mathrm{b}}$ & $0.23 \pm 0.02^{\mathrm{b}}$ \\
\hline \multirow{3}{*}{ gs } & PC & $450 \pm 0.04^{\mathrm{b}}$ & $106 \pm 0.00^{\mathrm{a}}$ & $440 \pm 0.03^{\mathrm{c}}$ & $95 \pm 0.00^{\mathrm{b}}$ & $510 \pm 0.02^{\mathrm{b}}$ & $116 \pm 0.07^{\mathrm{a}}$ \\
& PH & $410 \pm 0.01^{\mathrm{b}}$ & $82 \pm 0.00^{\mathrm{b}}$ & $620 \pm 0.04^{\mathrm{b}}$ & $96.6 \pm 0.00^{\mathrm{b}}$ & $410 \pm 0.01^{\mathrm{c}}$ & $62 \pm 0.00^{\mathrm{a}}$ \\
& PB & $550 \pm 0.08^{\mathrm{a}}$ & $63 \pm 0.00^{\mathrm{c}}$ & $720 \pm 0.06^{\mathrm{a}}$ & $102 \pm 0.00^{\mathrm{a}}$ & $630 \pm 0.06^{\mathrm{a}}$ & $110 \pm 0.04^{\mathrm{a}}$ \\
\hline \multirow{3}{*}{ WUE } & PC & $3.97 \pm 0.10^{\mathrm{c}}$ & $7.71 \pm 0.5^{\mathrm{b}}$ & $5.87 \pm 0.65^{\mathrm{a}}$ & $15.03 \pm 0.24^{\mathrm{c}}$ & $3.89 \pm 0.14^{\mathrm{c}}$ & $8.5 \pm 1.21^{\mathrm{c}}$ \\
& PH & $5.2 \pm 0.57^{\mathrm{b}}$ & $12.70 \pm 0.81^{\mathrm{a}}$ & $6.02 \pm 0.57^{\mathrm{a}}$ & $12.48 \pm 0.49^{\mathrm{a}}$ & $11 \pm 0.21^{\mathrm{a}}$ & $17.44 \pm 0.69^{\mathrm{a}}$ \\
& PB & $5.91 \pm 0.27^{\mathrm{a}}$ & $12.87 \pm 2.87^{\mathrm{a}}$ & $5.86 \pm 0.94^{\mathrm{a}}$ & $13.87 \pm 1.7^{\mathrm{a}}$ & $5.10 \pm 0.81^{\mathrm{b}}$ & $15.52 \pm 1.6^{\mathrm{b}}$ \\
\hline
\end{tabular}

An: Net assimilation rate Tr: transpiration rate gs: stomatal conductance WUE: water use efficiency, Sp: species, PC: Pinus canariensis, PH: P. halepensis and PB: P. brutia

In July, there was a high positive correlation between An and gs: $\mathrm{r}^{2}$ coefficient. The correlation was more important in P. halepensis, P. brutia, and P. canariensis in semiarid climate than others climates. The coefficients were $\left(r^{2}=0.623, r^{2}=0.58, r^{2}=0.95\right)$, respectively (Table 3 ).

\section{Stomatal control and twig water potentials}

Stomatal conductance was significantly lower in July than in March $(p<0.001)$ for all pine species. The highest rate of decline of stomatal conductance between the two months was recorded for $P$. halepensis, $P$. canariensis and $P$. brutia in semi-arid, sub- 
humid and humid climates, respectively. The rate of loss was $(84.87,78.41$ and $88.54 \%$ ), respectively (Table 2).

Twig water potentials revealed a significant difference between species $(\mathrm{p}<0.001)$, sites $(\mathrm{p}<0.001)$ and months $(\mathrm{p}<0.001)$. For any given species, there were differences among sites $(\mathrm{p}<0.001)$ and for any given site; there were differences among species $(p<0.001)$. The interaction between species and sites was significantly $(p<0.001)$.

Table 3. Correlation coefficient $r^{2}$ of An and $g s$ in July of P. halepensis, P. brutia and P. canariensis in Souiniet, Jebel Abderrahmane and Henchir Naam

\begin{tabular}{c|c|c|c}
\hline Sites & P. halepensis & P. brutia & P. canariensis \\
\hline Souiniet & 0.49 & 0.46 & 0.42 \\
Jebel Abderrahmane & 0.53 & 0.56 & 0.65 \\
Henchir Naam & 0.62 & 0.58 & 0.95 \\
\hline
\end{tabular}

An: Net assimilation rate, gs: stomatal conductance

The water potential decreases significantly from March to July in all pine species in different climates (sites). The lowest rates of decline of water potential between the two months were $17.91 \%, 31.40 \%$ for $P$. halepensis and P. canariensis in semi-arid climate. For $P$. brutia the lowest rate was $47.53 \%$ detected in humid climate (Table 4 ).

Table 4. Water potential ( $\Psi: M P a)$ of P. canariensis, P. halepensis, and P. brutia in two months March and July in Souiniet, Jebel Abderrahmane, and Henchir Naam. Mean $\pm S E$ with distinct letters are significantly different at $5 \%$ (SNK test)

\begin{tabular}{c|c|c|c|c|c|c}
\hline \multirow{2}{*}{ Pine species } & \multicolumn{2}{|c|}{ Souiniet } & Jebel Abderrahmane & \multicolumn{2}{c}{ Henchir Naam } \\
\cline { 2 - 7 } & March & July & March & July & March & July \\
\hline PC & $-1.54 \pm 0.01^{\mathrm{a}}$ & $-2.62 \pm 0.01^{\mathrm{c}}$ & $-1.68 \pm 0.01^{\mathrm{a}}$ & $-2.21 \pm 0.01^{\mathrm{a}}$ & $-2.42 \pm 0.01^{\mathrm{c}}$ & $-3.18 \pm 0.01^{\mathrm{c}}$ \\
PH & $-1.7 \pm 0.02^{\mathrm{c}}$ & $-2.58 \pm 0.01^{\mathrm{b}}$ & $-2.56 \pm 0.01^{\mathrm{c}}$ & $-3.47 \pm 0.02^{\mathrm{c}}$ & $-1.73 \pm 0.02^{\mathrm{b}}$ & $-2.04 \pm 0.00^{\mathrm{a}}$ \\
PB & $-1.62 \pm 0.01^{\mathrm{b}}$ & $-2.39 \pm 0.01^{\mathrm{a}}$ & $-1.92 \pm 0.00^{\mathrm{b}}$ & $-2.99 \pm 0.05^{\mathrm{b}}$ & $-1.57 \pm 0.00^{\mathrm{a}}$ & $-2.46 \pm 0.01^{\mathrm{b}}$ \\
\hline
\end{tabular}

PC: Pinus canariensis, PH: P. halepensis and PB: P. brutia

Stomatal conductance (gs) decreased significantly as VPD increased in July in three sites (Fig. 3). In July and under semi-arid climate with (VPD $=2.4 \mathrm{kPa})$, the lowest minimum rate in gs was recorded in Pinus halepensis $\left(62 \mathrm{mmol} \mathrm{m}^{-2} \mathrm{~s}^{-1}\right)$. While in a subhumid climate and with $(\mathrm{VPD}=1.68 \mathrm{kPa})$, stomatal conductance was lower in $P$. canariensis $\left(95 \mathrm{mmol} \mathrm{m}^{-2} \mathrm{~s}^{-1}\right)$. In a humid climate and with $(\mathrm{VPD}=1.9 \mathrm{kPa})$, P. brutia species recorded the lowest stomatal conductance value $\left(63 \mathrm{mmol} \mathrm{m}^{-2} \mathrm{~s}^{-1}\right)$.

\section{Soil water content}

Soil water content (SWC) showed significant differences between months $(p<0.001)$ and sites $(p=0.017)$. The interaction term was also significant $(p=0.02)$, being higher in March than in July (Table 5). In July, the correlation between soil water content and gs was high and positive for $P$. brutia, $P$. canariensis, and $P$. halepensis $\mathrm{r}^{2}=0.916, \mathrm{r}^{2}=0.798$ and $\mathrm{r}^{2}=0.931$, respectively in all sites. 
Soil water content was negatively correlated with WUE for all pine species under these climates: for $P$. halepensis, $P$. brutia and $P$. canariensis $(\mathrm{r}=-0.84 ; \mathrm{r}=-0.79 ; \mathrm{r}=-0.78)$, in a semi-arid, humid and sub-humid climate, respectively.

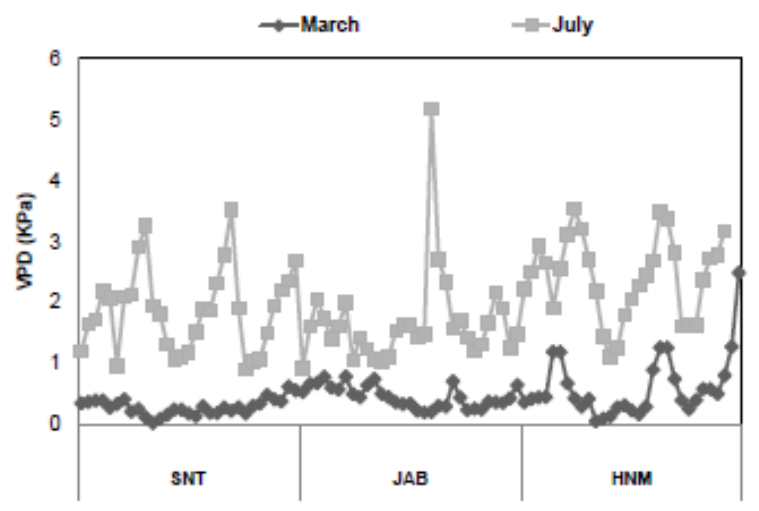

Figure 3. Vapor pressure deficit in $k P a(V P D)$ in March and July 2016 in SNT (Souiniet), JAB (Jbel Abderrahmane), and HNM (Henchir Naam)

Table 5. Soil water content (\%) for P. canariensis, P. halepensis, and P. brutia in three sites Souiniet, Jbel Abderrahmane, and Henchir Naam between March and July. Mean $\pm S E$ with distinct letters are significantly different at 5\% (SNK test)

\begin{tabular}{c|c|c|c|c|c|c}
\hline \multirow{2}{*}{ Pine species } & \multicolumn{2}{|c|}{ Souiniet } & \multicolumn{2}{c|}{ Jebel Abderrahmane } & \multicolumn{2}{c}{ Henchir Naam } \\
\cline { 2 - 7 } & March & July & March & July & March & July \\
\hline PC & $34.63 \pm 0.02^{\mathrm{c}}$ & $17.43 \pm 0.01^{\mathrm{b}}$ & $47.80 \pm 0.01^{\mathrm{a}}$ & $19.23 \pm 0.01^{\mathrm{ab}}$ & $35 \pm 0.01^{\mathrm{b}}$ & $21.13 \pm 0.01^{\mathrm{a}}$ \\
PH & $58.43 \pm 0.01^{\mathrm{a}}$ & $21.93 \pm 0.03^{\mathrm{a}}$ & $45.90 \pm 0.02^{\mathrm{ab}}$ & $17.72 \pm 0.02^{\mathrm{b}}$ & $48.57 \pm 0.01^{\mathrm{b}}$ & $19.82 \pm 0.00^{\mathrm{a}}$ \\
PB & $48.43 \pm 0.01^{\mathrm{b}}$ & $19.46 \pm 0.01^{\mathrm{b}}$ & $44.67 \pm 0.02^{\mathrm{ab}}$ & $20.80 \pm 0.05^{\mathrm{a}}$ & $43.93 \pm 0.00^{\mathrm{a}}$ & $18.60 \pm 0.03^{\mathrm{a}}$ \\
\hline
\end{tabular}

PC: P. canariensis; PH: P. halepensis, and PB: P. brutia

\section{Discussion}

\section{Ecophysiological measurements and stomatal control}

Drought may reduce leaf net carbon assimilation by both stomatal and metabolic limitations (Farquhar and Sharkey, 1982). In addition, the decrease in stomatal conductance is the main factor of photosynthesis inhibition during dehydration as previously reported (Cornic and Fresneau, 2002; Flexas and Medrano, 2002).

In this study, a significant decrease in "gs" and "An" was found in July in $P$. halepensis, $P$. canariensis and $P$. brutia under different climates compared to results of March. Both parameters (gs and An) plummeted concomitantly as aridity increased. In Spain, Manzanera et al. (2016) found the same results on Pinus sylvestris, Pinus pinea and Pinus halepensis.

In our study, $P$. halepensis, $P$. canariensis and $P$. brutia suggest a higher stomatal control and decreased their water potential in semi-arid, sub-humid and humid climate, respectively to a lesser in the other climates. Also a strong reduction of stomatal conductance under drought conditions slows transpiration allowing plants to keep high water potentials (Table 2).

In France, Lebourgeois et al. (1998) found that pine species were tolerant to drought and a significant decrease of stomatal conductance of Pinus nigra was not correlated 
with obvious variation in water potential. They usually exhibit drought avoidance strategy with efficient stomatal control of transpiration loss, a decrease of stomatal conductance (up to $30 \%$ ) and no change in water potential.

In July, our results (Table 2) revealed that the net carbon assimilation of Pinus halepensis was lower in humid climate $\left(3.43 \mu \mathrm{mol} \mathrm{m} \mathrm{m}^{-2} \mathrm{~s}^{-1}\right)$ than sub-humid climate $\left(4.12 \mu \mathrm{mol} \mathrm{m} \mathrm{m}^{-2} \mathrm{~s}^{-1}\right)$. However, Aleppo pine showed a higher assimilation rate than the other pine species in semi-arid climate $\left(4.36 \mu \mathrm{mol} \mathrm{m} \mathrm{m}^{-2} \mathrm{~s}^{-1}\right)$. Similarly, in Spain, SalazarTortosa et al. (2018) found that net carbon assimilation in P. halepensis was $\left(3.4 \mu \mathrm{mol} \mathrm{m} \mathrm{m}^{-2} \mathrm{~s}^{-1}\right)$ in the same season July 2014. It can maintain $\mathrm{CO}_{2}$ uptake and photosynthesis by mean lower stomatal control.

The net carbon assimilation of $P$. canariensis was lower in July in semi-arid than humid climate but it maintain the high value in sub-humid climate. While, for P. brutia the net carbon assimilation was lower in semi arid climate but it can keep a high net assimilation in humid and sub-humid climates (Table 2).

\section{Ecophysiological mechanisms driving WUE enhancement}

In March and July, physiological activity and phenological development of the three pines species were critical. In March water availability in the soil was important and the radiation was not excessive, which leads to having a maximum value of photosynthesis, and the development of shoots and needles began. Whereas, in July water availability in the soil was limited; the radiation was excessive and lead to having minimal photosynthesis. The development of the shoots was complete and that of the needles was in progress.

For all studied pine species, the large fluctuations in WUE between March and July appear to be mainly related to changes in environmental conditions (soil water content, precipitation and temperature). Thus, soil water content was negatively correlated with WUE for all pine species under semi-arid, humid and sub-humid climate. These results revealed the degree of adaptation and resistance of three pine species particularly in these climates under drought conditions. The significant interaction observed between site (climate) and species clarify the behaviour of each pine species: Pinus canariensis have better water use efficiency in sub-humid than in humid and semi-arid. Pinus brutia have a high water use efficiency in the three sites with pronounced value in semi-arid. However, Aleppo pine showed higher water-use efficiency in different climates, supporting the notion that assimilation was less limited by climatic conditions (Table 1). As far as Klein et al. (2012) found that Aleppo pine has the ability to survive and grow in various environments indicates thus is a highly tolerant species. In contrary to previous study realized by Sardans and Peñuelas (2007) and Vila et al. (2008) confirmed that Aleppo pine is expected to suffer from changes in timing and duration of drought, particularly in spring and summer.

\section{The effect of VPD and soil water content on stomatal response of pine species}

Oren et al. (1999) emphasized that high VPD may be one of the signals that lead to stomatal closure. In our study, stomatal conductance decreased in July for all pine species in different climates with the increase of the VPD. Both high VPD and low SWC explained the reductions in stomatal conductance, transpiration and photosynthesis in all pine species under different climates (Table 2). The results were also in agreement with those reported in USA by Sulman et al. (2016) that worked on 
Acer saccharum, Liriodendron tulipifera, Sassafras albidum, Quercus alba, Quercus velutina, and Quercus rubra. Under drought conditions and with low SWC or high VPD, these 5 plant species close stomata reduce transpiration and photosynthesis.

$P$. brutia was more resistant to drought in two climates humid and semi arid. Awada et al. (2003) showed that $P$. brutia was a drought-resistant species occupying the driest sites around the Mediterranean Basin. Furthermore, P. canariensis was resistant to drought in the three climates in Tunisia with less tolerance to humid climate. Jiménez et al. (2005) showed that $P$. canariensis was able to modulate its physiology (with a good stomatal control), depending of the site where it grows with. However, the performance of $P$. halepensis was much higher as much as this species exhibited higher stomatal control, higher photosynthesis and water use efficiency in a dry month (July) and under semi-arid climates. Salazar-Tortosa et al. (2018) showed that Aleppo pine would require less water in the carbon capture process when it is planted with limited water availability. This strategy allowed $P$. halepensis to be one of the more conservative species.

\section{Conclusion}

The findings showed significant differences in leaf water potential and gas exchange measurements among pine species. The responses are depending not only on species but also on the climate in which they grow.

Under dry conditions, $P$. halepensis, $P$. canariensis and $P$. brutia are better adapted to a semi-arid, sub-humid and humid climate, respectively. All pine species avoid drought by reducing stomatal conductance to water through conservation of soil water content at high VPD and thus avoiding future drought. While this strategy would result in a net increase in WUE, it would be at the expense of photosynthesis during periods of high VPD. The findings of these experiments may help to quantify the impact of midsummer water deficit on Mediterranean pines and evaluate their potential responses to future climate regimes. Monitoring of these three species is required to reveal how ecological restoration is progressing and where management interventions are required.

Therefore, in Tunisia, it is highly recommended to plant $P$. halepensis in semi-arid climate, $P$. brutia was recommended to be planted in humid and semi-arid climates. While, it is recommended to plant $P$. canariensis in sub-humid and semi-arid climates.

Acknowledgements. This work was supported and funded by the INCREDIBLE project (funding from the European Union's Horizon 2020 research and innovation programme under grant agreement $\mathrm{N}^{\circ}$ 774632). Thanks to Mokhtar Baraket for his considerable comments for manuscript and thanks to National Institute of Meteorology of Tunis for providing meteorological data from different regions.

\section{REFERENCES}

[1] Allen, C. D., Macalady, A. K., Chenchouni, H., Bachelet, D., McDowell, N., Vennetier, M., Kitzberger, T., Rigling, A., Breshears, D. D., Hogg, E. H., Gonzalez, P., Fensham, R., Zhang, Z., Castro, J., Demidova, N., Lim, J. H., Allard, G., Running, S. W., Semerci, A., Cobb, N. (2010): A global overview of drought and heat-induced tree mortality reveals emerging climate change risks for forests. - Forest Ecology and Management 259: 660684. 
[2] Awada, T., Radoglou, K., Fotelli, M. N., Constantinidou, H. I. (2003): Ecophysiology of seedlings of three Mediterranean pine species in contrasting light regimes. - Tree Physiology 23(1): 33-41.

[3] Ayari, A., Moya, D., Zubizarreta-Gerendiain, A. (2012): Influence of Enviromental Factors on Aleppo Pine Forest Production. - Nova Science Publishers, Inc., Hauppauge, NY.

[4] Bréda, N., Cochard, H., Dreyer, E., Granier. A. (1993): Water transfer in a mature oak stands (Quercus petraea): seasonal evolution and effects of a severe drought. - Canadian Journal of Forest Research 23: 1136-1143.

[5] Choat, B., Jansen, S., Brodribb, T. J., Cochard, H., Delzon, S., Bhaskar, R., Bucci, S. J., Field, T. S., Gleason, S. M., Hacke, U. G., Jacobsen, A. L., Lens, F., Maherali, H., Martinez-Vilalta, J., Mayr, S., Mencuccini, M., Mitchell, P. J., Nardini, A., Pittermann, J., Pratt, R. B., Sperry, J. S., Westoby, M., Wright, I. J., Zanne, A. E. (2012): Global convergence in the vulnerability of forests to drought. - Nature 491: 752-755.

[6] Cornic, G., Fresneau, C. (2002): Photosynthetic carbon reduction and carbon oxidation cycles are the main electron sinks for photosystem II activity during a mild drought. Annals of Botany 89: 887-894.

[7] David, T. S., Henriques, M. O., Kurz-Besson, C., Nunes, J., Valente, F., Vaz, M., Pereira, J. S., Siegwolf, R., Chaves, M. M., Gazarini, L. C., David, J. S. (2007): Water-use strategies in two co-occurring Mediterranean evergreen oaks: surviving the summer drought. - Tree Physiology 27: 793-803.

[8] de Nascimento, L., Willis, K. J., Fernández-Palacios, J. M, Criado, C., Whittaker, R. J. (2009): The long-term ecology of the lost forests of La Laguna. Tenerife (Canary Islands). - Journal of Biogeography 36: 499-514.

[9] Khouja, M. L. (2001): Amélioration génétique: inventaire et bilan des recherches entreprises en Tunisie. - Annales de l'INRGREF 5: 1-44.

[10] Khouja, M. L., Sghaier, T., Khaldi, A., Nouri, M., Souayah, N. (2002): Premiers résultats des essais de provenances de Pinus brutia TEN en Tunisie. - Annales de l'INRGREF 5: 57-70.

[11] Farquhar, G. D., Sharkey, T. D. (1982): Stomatal conductance and photosynthesis. Annual Review of Plant Physiology 33: 317-345.

[12] Flexas, J., Medrano, H. (2002): Drought-inhibition of photosynthesis in C3 plants: stomatal and non-stomatal limitations revisited. - Annals of Botany 89(2): 183-9.

[13] Granier, A., Bréda, N., Longdoz, B., Gross, P., Ngao, J. (2008): Ten years of fluxes and stand growth in a young beech forest at Hesse, North-eastern France. - Annals of Forest Science 64: 704.

[14] Jiménez, M. S., Luis, V. C., Peters, J., González-Rodríguez, A., Morales, D. (2005): Ecophysiological studies on Pinus canariensis Phyton. - Annales Rei Botanicae 45(3): 169-177.

[15] Klein, T., Cohen, S., Yakir, D. (2011): Hydraulic adjustments underlying drought resistance of Pinus halepensis. - Tree Physiology 31(6): 637-648.

[16] Klein, T., Di Matteo, G., Rotenberg, E., Cohen, S., Yakir, D. (2012): Differential ecophysiological response of a major Mediterranean pine species across a climatic gradient. - Tree Physiology 33(1): 26-36.

[17] Kucuk, O., Bilgili, E., Bulut, S., Fernandes, P. M. (2012): Rates of surface fire spread in a young calabrian pine (pinus brutia ten.) plantation - Environmental Engineering and Management Journal 11: 1475-148.

[18] Lebourgeois, F., Levy, G., Aussenac, G., Clerc, B., Willm, F. (1998): Influence of soil drying on leaf water potential, photosynthesis, stomatal conductance and growth in two black pine varieties. - Annals of Forest Science 55: 287-299.

[19] Letts, M. G., Rodriguez-Calcerrada, J., Rolo, V., Rambal, S. (2011): Long term physiological and morphological acclimation by the evergreen shrub Buxus sempervirens L. to understory and canopy gap light intensities. - Trees 26: 479-491. 
[20] López, R., Cano, F. G., Choat, B., Cochard, H., Gil, L. (2016): Plasticity in Vulnerability to cavitation of pinus canariensis occurs only at the driest end of an aridity gradient. Frontiers in Plant Science 3: 7-769.

[21] Manzanera, J. A., Martinez-Chacon, M. F. (2007): Ecophysiological competence of Populus alba L., Fraxinus angustifolia Vahl. and Crataegus monogyna Jacq used in plantations for the recovery of riparian vegetation. - Journal of Environmental Management 40(6): 902-912.

[22] Manzanera, J. A., Gómez-Garay, A., Pintos, B., Rodríguez-Rastrero, M., Moreda, E., Zazo, J., Martínez-Falero, E., García-Abril, A. (2016): Sap flow, leaf-level gas exchange and spectral responses to drought in Pinus sylvestris, Pinus pinea and Pinus halepensis. iForest 10: 204-214.

[23] Martínez-Vilalta, J., Sala, A., Piñol, J. (2004): The hydraulic architecture of Pinaceae-a review. - Plant Ecology 171(1): 3-13.

[24] Martínez-Vilalta, J., Cochard, H., Mencuccini, M., Sterck, F., Herrero, A., Korhonen, J. F., Llorens, P., Nikinmaa, E., Nole, A., Poyatos, R., Ripullone, F., Sass-Klaassen, U., Zweifel, R. (2009): Hydraulic adjustment of scots pine across Europe. - New Phytologist 184(2): 353-64.

[25] Matías, L., Jump, A. S. (2012): Interactions between growth, demography and biotic interactions in determining species range limits in a warming world: the case of Pinus sylvestris. - Forest Ecology and Management 282: 10-22.

[26] McDowell, N., Pockman, W. T., Allen, C. D., Breshears, D. D., Cobb, N., Kolb, T., Plaut, J., Sperry, J., West, A., Williams, D. G., Yepez, E. A. (2008): Mechanisms of plant survival and mortality during drought: why do some plants survive while others succumb to drought? - New Phytologist 178: 719-739.

[27] Mittler, R. (2002): Oxidative stress, antioxidants and stress tolerance. - Trends in Plant Science 7(9): 405-410.

[28] Nemani, R. R., Keeling, C. D., Hashimoto, H., Jolly, W. M., Piper, S. C., Tucker, C. J., Myneni, R. B., Running, S. W. (2003): Climate-driven increases in global terrestrial net primary production from 1982 to 1999. - Science 300: 1560-1563.

[29] Oren, R., Sperry, J. S., Katul, G. G., Pataki, D. E., Ewers, B. E., Phillips, N., Schaefer, K. V. R. (1999): Survey and synthesis of intra- and interspecific variation in stomatal sensitivity to vapour pressure deficit. - Plant, Cell \& Environment 22: 1515-1526.

[30] Peñuelas, J., Sardans, J., Filella, I., Estiarte, M., Llusià, J., Ogaya, R., Carnicer, J., Bartrons, M., Rivas-Ubach, A., Grau, O., Peguero, G., Margalef, O., Pla-Rabés, S., Stefanescu, C., Asensio, D., Preece, C., Liu, L., Verger, A., Barbeta, A., AchoteguiCastells, A., Gargallo-Garriga, A., Sperlich, D., Farré-Armengol, G., FernándezMartínez, M., Liu, D., Zhang, C., Urbina, I., Camino-Serrano, M., Vives-Ingla, M. D., Stocker, B., Balzarolo, M., Guerrieri, R., Peaucelle, M., Marañón-Jiménez, S., BórnezMejías, K., Mu, Z., Descals, A., Castellanos, A., Terradas, J. (2017): Impacts of global change on Mediterranean forests and their services. - Forests 8: 12-463.

[31] Ramirez-Valiente, J. A., Sánchez-Gómez, D., Aranda, I., Valladarres, F. (2010): Phenotypic plasticity and local adaptation in leaf ecophysiological traits of 13 contrasting cork oak populations under different water availabilities. - Tree Physiology 30: 618-627.

[32] Rubio-Casal, A. E., Leira-Doce, P., Figueroa, M. E., Castillo, J. M. (2010): Contrasted tolerance to low and high temperatures of three tree taxa co-occurring on coastal dune forests under Mediterranean climate. - Journal of Arid Environments 74: 429-439.

[33] Santiago, L. S., Mulkey, S. S. (2003): A test of gas exchange measurements on excised canopy branches of ten tropical tree species. - Photosynthetica 41: 343-347.

[34] Salazar-Tortosa, D., Castro, J., Rubio de Casas, R., Vĩnegla, B., S'anchez-Cãnete, E. P., Villar-Salvador, P. (2018): Gas exchange at whole plant level shows that a less conservative water use is linked to a higher performance in three ecologically distinct pine species. - Environmental Research Letters 13: 045004. 
[35] Sardans, J., Peñuelas, J. (2007): Drought changes the dynamics of trace element accumulation in a Mediterranean Quercus ilex forest. - Environmental Pollution 147(3): 567-583.

[36] Scholander, P. F., Bradstreet, E. D., Hemmingsen, E. A., Hammel, H. T. (1965): Sap pressure in vascular plants: negative hydrostatic pressure can be measured in plants. Science 148: 339-346.

[37] Sulman, B. N., Roman, D. T., Yi, K., Wang, L., Phillips, R. P., Novick, K. A. (2016): High atmospheric demand for water can limit forest carbon uptake and transpiration as severely as dry soil. - Geophysical Research Letters 43: 9686-9695.

[38] Vila, B., Vennetier, M., Ripert, C., Chandioux, O., Liang, E., Guibal, F., Torre, F. (2008): Has global change induced opposite trends in radial growth of Pinus sylvestris and Pinus halepensis at their bioclimatic limit? The example of the Sainte-Baume forest (south-east France). - Annals of Forest Science 65: 709.

[39] Warren, C. R., McGrath, J. F., Adams, M. A. (2001): Water availability and carbon isotope discrimination in conifers. - Oecologia 127: 476-486.

[40] Will, R. E., Wilson, S. M., Zou, C. B., Hennessey, T. C. (2013): Increased vapor pressure deficit due to higher temperature leads to greater transpiration and faster mortality during drought for tree seedlings common to the forest-Grassland ecotone. - New Phytologist 200: 366-374.

[41] You, H., Jinb, H., Khaldi, A., Kwaka, M., Lee, T., Khainea, I., Janga, J., Lee, H., Kim, I., Ahn, T., Song, J., Song, Y., Khorchani, A., Stiti, B., Woo, S. (2016): Plant diversity in different bioclimatic zones in Tunisia. - Journal of Asia-Pacific Biodiversity 9: 56-62. 